\title{
EVALUATING THE USE OF Atriplex nummularia HAY ON FEED INTAKE, GROWTH, AND CARCASS CHARACTERISTICS OF CREOLE KIDS
}

\author{
Raúl Meneses $^{1 *}$, Gabriel Varela ${ }^{1}$, and Hugo Flores ${ }^{2}$
}

There is a surplus of Atriplex nummularia Lindl. grazing that can be used as animal feed. This material was harvested to assess the effects on intake, growth, and carcass characteristics of kids. Atriplex replaced alfalfa hay (Medicago sativa L.) in a proportion of $0 \%, 10 \%, 20 \%, 30 \%$, and $40 \%$ for 60 creole kids weighing $13 \mathrm{~kg}$ and was assigned to the diets in a completely randomized design. The process was conducted from March to May. Two males and two females were used from each group to evaluate individual nutrient intake. Height at withers, thoracic diameter, and weight change were evaluated in all the animals. The carcasses of four females per group were evaluated. Offered and rejected hay diet samples were chemically analyzed. Atriplex hay crude protein $(\mathrm{CP})$, metabolizable energy $(\mathrm{ME})$, chlorine $(\mathrm{Cl})$, and sodium $(\mathrm{Na})$ contents were $20.20 \%, 1.99 \mathrm{Mcal} \mathrm{kg}^{-1}, 4.78 \%$, and $6.47 \%$ respectively. Hemicellulose (Hc), ash intake, height at withers, thoracic diameter, and carcass component, except for the kidney, were not different $(\mathrm{P}>0.05)$ among treatments. Over $20 \%$ of $A$. nummularia hay content in the diet caused an increase in mineral consumption $(\mathrm{P}<0.05)$. Total body weight gain decreased $(\mathrm{P}<0.05)$ by adding $20 \%$ or more $A$. nummularia hay content in the diet. However, adding up to $20 \%$ of $A$. nummularia hay in the diet did not produce a negative effect and higher percentages decreased weight gains attributable to the high $\mathrm{Na}$ and $\mathrm{Cl}$ content.

Key words: Atriplex nummularia, goats, hay.

$\mathrm{T}$ here are about 65000 ha of Atriplex repanda (Sereno), Atriplex nummularia Lindl., and Acacia saligna (Labill.) H. L. Wendl. plantations in the coastal area of the Coquimbo Region, Chile. They were planted in 1976 to revegetate degraded and overgrazed areas and provide forage for goats and sheep during the annual dry period. Most of these plantations consist of A. nummularia. Drought resistance is a characteristic that allows it to be grazed during the annual dry period when there are no other available forage resources (Ben Salem et al., 2010). The chemical composition of A. nummularia edible dry matter (EDM) consists of 10.3 to $25.9 \%$ crude protein (CP) and 17.9 to $35.4 \%$ ash as evaluated in different countries (Ben Salem et al., 2010). In Chile, Meneses and Squella (1996) reported $16.3 \% \mathrm{CP}$ and $22.9 \%$ ash. Atriplex nummularia also contains high concentrations of $\mathrm{S}, \mathrm{Mg}, \mathrm{Ca}, \mathrm{P}, \mathrm{Na}$, and $\mathrm{KCl}$ (Aganga et al., 2003). In some cases, these components can decrease food consumption and produce mineral imbalances and improve product quality, such as wool production, in other cases due to $\mathrm{S}$ concentration (Norman et al., 2004; 2008).

${ }^{1}$ Instituto de Investigaciones Agropecuarias INIA, Apartado Postal 36B, La Serena, Chile. *Corresponding author (rmeneses@inia.cl).

${ }^{2}$ Instituto de Investigaciones Agropecuarias INIA, Casilla 439/3, Santiago, Chile.

Received: 22 June 2011.

Accepted: 20 December 2011
Consumption of A. nummularia by sheep is between 37 to $115 \mathrm{~g} \mathrm{DM} \mathrm{kg}{ }^{-1} \mathrm{BW}^{0.75}$, which is considered low because of the high salt content, higher drinking water requirements (Masters et al., 2005a; 2005b), and Atriplex non-protein nitrogen, which requires higher energy for microorganism metabolism (Ben Salem, 2002a). Sheep nutritional supplementation with one third of their energy requirements improves body weight gain, body condition, and wool production (Norman et al., 2008). Thomas et al. (2007) also concluded that animals grazing on $A$. nummularia require energy supplementation more than any other kind of supplementation.

Many stockbreeders graze their A. nummularia plantations with sheep and goats before the rainy season in the summer and fall. Others do not apply this method; consequently, crops increase in size and limit small ruminant grazing. This causes an excess of unconsumed leaves that are wasted. Another reason for unconsumed leaves is their low acceptability. The high mineral content and other chemical components limit its consumption (Aganga et al., 2003). This species needs to be harvested or grazed at least once a year to stimulate annual growth; otherwise, there will be leaf loss and decrease in its production (Wilmot and Norman, 2006). Another advantage of removing excess material is increasing vegetation coverage under its canopy projection and herbaceous dry matter (DM) production (Lailhacar and Torres, 2001). 
The excess of Atriplex leaves can be harvested, dried, stored, and used to feed animals that do not have access to this forage during the dry period. This resource combined with other ingredients can also be a good feeding alternative for sheep and goats during the summer and fall by achieving the dilution of salts in a balanced diet and improving animal consumption and nutrient level. The objective of this study was to evaluate the effect on diet intake, growth, and carcass characteristics by including Atriplex nummularia in a basal diet of alfalfa hay (Medicago sativa $\mathrm{L}$.) offered to creole kids under stabling conditions.

\section{MATERIALS AND METHODS}

Atriplex nummularia leaves were harvested on January 4 and 5 from a 10-yr-old plantation located in El Tangue Ranch (30³1'30.27' S, 71 $27^{\prime} 42.76^{\prime \prime}$ E) in the Coquimbo Region, Chile. The harvested material consisted of about $14000 \mathrm{~kg}$ of green material that was transported to the Santa Cristina farm $\left(30^{\circ} 20^{\prime} 51.38^{\prime \prime} \mathrm{S}, 71^{\circ} 83^{\prime} 32.09^{\prime \prime} \mathrm{E}\right)$. Once there, it was distributed for dehydration over a Rachel net located on a wire net $(3 \times 12 \mathrm{~m})$ and both nets were supported by six posts $1 \mathrm{~m}$ high. Material samples were obtained every $2 \mathrm{~d}$ to determine DM according to AOAC (1990) and control the dehydration process until it reached $20 \%$ humidity. After the dehydration process, A. nummularia and alfalfa hay were chopped with a 5 $\mathrm{cm}$ screening mill for the experimental diets. Atriplex nummularia hay was mixed with alfalfa hay in a mixer at $10 \%, 20 \%, 30 \%$, and $40 \%$ ratios.

Sixty goat kids, 2-mo-old and $13 \mathrm{~kg} \mathrm{LW}$, were randomly selected from a dairy farm located nearby. These animals were submitted to a $21 \mathrm{~d}$ pre-experimental period in a community pen with only an alfalfa hay basal diet with $40 \%$ A. nummularia offered ad libitum to get used to the Atriplex intake. Animals were assigned to five experimental groups each consisting of three males and nine females and maintained in a community pen for $61 \mathrm{~d}$. Two females and two males were selected from each group to evaluate individual intake in an individual pen. Weighed feed and water in buckets were offered. Experimental diets were offered twice a day at 09:00 and 17:00 $\mathrm{h}$ and were adjusted daily in each group so that there would always be at least $10 \%$ rejection to avoid selection in diet consumption.

Experimental measurements began in March with daily evaluations of the amount of food offered and rejected. The samples obtained in the individual and community groups were oven-dried at $60{ }^{\circ} \mathrm{C}$ for $62 \mathrm{~h}$ (AOAC, 1990). At the end of the trial, all rejected samples were mixed to obtain only one sample from each experimental group for chemical analysis. These samples, offered and rejected A. nummularia and alfalfa hay, were sent to the Remehue Laboratory, Osorno for chemical analyses. Dry matter (DM) content was oven-dried at $105^{\circ} \mathrm{C}$ by forced air for $24 \mathrm{~h}$. Crude protein (CP) was obtained as $\mathrm{N}$ by micro Kjeldahl analysis and then calculated as $6.25 \times \mathrm{N}$ content (AOAC, 1990). Metabolizable energy (ME) was determined by organic matter digestibility estimation (Tilley and Terry, 1963). Neutral detergent fiber (NDF) and acid detergent fiber (ADF) were measured with a Fiber digester (Labconco, USA) and lignin by the $72 \%$ sulfuric acid method (ADL). Hemicellulose and cellulose were obtained by the differences between NDF ADF and ADF ADL, respectively (van Soest, 1963). Ash was determined by ashing at $550{ }^{\circ} \mathrm{C}$ for $4 \mathrm{~h}$ (AOAC, 1990). With these data it was possible to calculate the amount of nutrients consumed as the difference between offered and rejected food in both individual and community groups.

Body weight, thoracic diameter, and height at withers were evaluated every $7 \mathrm{~d}$. At the end of the growth evaluation, four females were slaughtered in the field after a $12 \mathrm{~h}$ tare (Meneses et al., 2004). Live weights were obtained before slaughtering and weight of blood, skin, autopods, full and empty digestive tract, heart, liver, kidney, and lungs plus trachea, warm and cold carcass weight with and without the head, and eye loin area between the $12^{\text {th }}$ and $13^{\text {th }}$ rib was measured by copying the muscle perimeter on transparent paper and then determining the area with a planimeter (Digital Koizumi Lacom kp-80, Japan) according to the description by López et al. (1992) and Meneses et al. (2004). All this data made it possible to calculate the empty live weight (animal weight minus ruminal content), commercial yield (carcass weight/live body weight), true yield (carcass weight/empty body weight), red stripping yield (heart, liver, and lung plus trachea), head yield, empty digestive tract, skin, and autopods as the ratio between the respective component weight and empty weight (López et al., 1992).

Data were analyzed with ANOVA by the SAS GLM procedure (SAS Institute, 1998) in a random design with five treatments and four replicates for the intake variable, 12 replicates for growth evaluation, and four replicates for carcass measurement. Data were subjected to ANOVA and Duncan's test (Steel and Torrie, 1980) to establish differences among treatments. Different regression models were also evaluated to determine a better relationship for kid body total gain and A. nummularia inclusion percentage.

\section{RESULTS AND DISCUSSION}

\section{Chemical composition of Atriplex nummularia hay}

The chemical composition of A. nummularia (Table 1) depends on EDM, i.e., the leaf and stem proportion obtained from the harvested material (Norman et al., 2004). Although, in this case, the leaf proportion represents half of total DM (Table 2) and leaf CP content is generally higher than stem CP content (Jahn et al., 2003), this component is in the $10 \%$ to $25 \%$ range reported by Ben Salem et al. (2010) and is superior to the raw CP content 
Table 1. Chemical analyses of Atriplex nummularia and alfalfa hay.

\begin{tabular}{lcc}
\hline & \multicolumn{2}{c}{ Hay } \\
\cline { 2 - 3 } Nutrients & Alfalfa & A. nummularia \\
\hline Dry matter, \% & 89.70 & 88.10 \\
Crude protein, \% & 16.00 & 20.20 \\
Neutral detergent fiber, \% & 41.40 & 35.20 \\
Acid detergent fiber, \% & 30.70 & 17.10 \\
Hemicellulose, \% & 10.70 & 18.10 \\
Lignin, \% & 8.10 & 5.10 \\
Cellulose, \% & 22.60 & 12.00 \\
Ash, \% & 9.90 & 28.30 \\
Metabolizable energy, Mcal & 2.21 & 1.99 \\
Chloride, \% & 0.45 & 4.78 \\
Sodium, \% & 0.18 & 6.47 \\
\hline
\end{tabular}

Table 2. Leaf and stem proportions of Atriplex nummularia hay.

\begin{tabular}{lc}
\hline Components & Percentage \\
\hline Leaf & 54.44 \\
Stem 2-4 mm & 7.04 \\
Stem 4-6 mm & 14.52 \\
Stem 6-8 mm & 24.19 \\
\hline
\end{tabular}

in the alfalfa hay that was used. The high ash content of Atriplex is a result of the high $\mathrm{Na}$ and $\mathrm{Cl}$ content. The species of the genus Atriplex is characterized by its high salt content as well as its high levels of $\mathrm{S}, \mathrm{Mg}, \mathrm{Ca}, \mathrm{P}$, and other chemical components (Masters et al., 2007). The $\mathrm{Cl}$ and $\mathrm{Na}$ content in A. nummularia are 10.6 and 36 times more than the $\mathrm{Cl}$ and $\mathrm{Na}$ content in alfalfa, respectively. The ME in A. nummularia is $10 \%$ lower than alfalfa ME. Ben Salem et al. (2002b) indicate that A. nummularia exhibits low energy content, which could be a limiting factor to cover animal requirements. Norman et al. (2008) establish that energy content does not cover the lamb's energy requirements and calculations obtained in this research found that the amount of energy is limiting to some extent. The other chemical components were similar to those reported by the aforementioned authors.

\section{Nutrient intake}

Dry matter, $\mathrm{CP}, \mathrm{NDF}, \mathrm{ADF}$, lignin, and $\mathrm{ME}$ intake were not significantly different $(\mathrm{P}<0.05$, Table 3$)$. According to NRC (1981), nutrient requirements were $30.64 \mathrm{~g}$ and $0.781 \mathrm{Mcal}$ for $\mathrm{CP}$ and ME, respectively, for these animals; furthermore, according to NRC (1981) recommendations, ingested nutrients were very similar for $\mathrm{CP}$ and limiting for $\mathrm{ME}$ in $21.5 \%, 23.34 \%$, and $23.79 \%$ for treatments with $10 \%, 20 \%, 30 \%$, and $40 \%$ A. nummularia, although statistical analysis showed no significant differences in energy consumption. The increase of ash ingestion is determined by its high content in A. nummularia and limits consumption of dry material (Norman et al., 2004).

In the evaluation of the rejected diet component (Table 4), more Atriplex leaves than stems in feeding were found for all A. nummularia treatments and both numbers were higher than the rejected leaves and stems of alfalfa hay.

\section{Thoracic diameter and height at withers}

Thoracic diameter and height at withers did not show any significant differences (Tables 5 and 6). During the first week, evaluated thoracic diameter showed a tendency to decrease in size, which can be attributed to stress produced by the beginning of the trial, although these animals had an acclimatization period in a community paddock with a higher percentage of A. nummularia in their diet.

By the end of the evaluation period, thoracic diameter had a slight tendency to decrease with the increasing inclusion of Atriplex hay in the diet. Unlike thoracic diameter, height at withers always exhibited growth because thoracic diameter depends on muscle volume and fat accumulation and height depends on bone length.

\section{Weight gain}

Partial body weight variations, not included in this text, did not show any differences $(\mathrm{P}>0.05)$. However, the treatment produced differences in body weight gain $(\mathrm{P}$ $<0.05)$ at the beginning and end of the evaluation with negative weight gains (Table 7, Figure 1).

At the beginning, there was probably an adaptation effect to the diets even though there was an acclimatization

Table 4. Rejected component as percentage of diet with different proportions of Atriplex nummularia hay.

\begin{tabular}{|c|c|c|c|}
\hline A. nummularia & $\begin{array}{l}\text { Alfalfa } \\
\text { hay }\end{array}$ & $\begin{array}{l}\text { A. nummularia } \\
\text { hay leaf }\end{array}$ & $\begin{array}{l}\text { A. nummularia } \\
\text { hay stem }\end{array}$ \\
\hline \multicolumn{4}{|c|}{$\%$} \\
\hline 0 & 100.0 & 0.0 & 0.0 \\
\hline 10 & 40.0 & 46.7 & 13.3 \\
\hline 20 & 30.8 & 38.5 & 30.8 \\
\hline 30 & 23.3 & 40.0 & 36.7 \\
\hline 40 & 23.4 & 29.7 & 46.9 \\
\hline
\end{tabular}

Table 3. Total nutrient intake of kids fed different proportions of Atriplex nummularia hay.

\begin{tabular}{|c|c|c|c|c|c|c|c|c|c|}
\hline A. nummularia & DM & $\mathrm{CP}$ & NDF & $\mathrm{ADF}$ & $\mathrm{Hc}$ & Celul & Lig & Ash & $\mathrm{ME}$ \\
\hline$\%$ & & & & 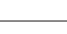 & 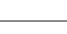 & & & - & Mcal kg-1 \\
\hline 0 & 72.8 & 12.5 & 33.8 & 25.2 & $8.7 \mathrm{a}$ & $18.5 \mathrm{a}$ & 6.6 & $7.8 \mathrm{~b}$ & 2.21 \\
\hline 10 & 65.8 & 12.7 & 30.7 & 24.7 & $5.8 \mathrm{~b}$ & $18.5 \mathrm{a}$ & 6.2 & $7.9 \mathrm{~b}$ & 2.19 \\
\hline 20 & 66.8 & 11.7 & 30.7 & 23.9 & $6.8 \mathrm{~b}$ & $17.3 \mathrm{ab}$ & 6.7 & $9.3 \mathrm{ab}$ & 2.17 \\
\hline 30 & 65.9 & 13.3 & 30.3 & 21.0 & $9.2 \mathrm{a}$ & $14.8 \mathrm{a}$ & 6.1 & $9.8 \mathrm{a}$ & 2.14 \\
\hline 40 & 66.2 & 12.0 & 31.2 & 21.4 & $9.4 \mathrm{a}$ & $15.8 \mathrm{~b}$ & 5.6 & $11.1 \mathrm{a}$ & 2.12 \\
\hline $\mathrm{CV}, \%$ & 14.0 & 13.9 & 14.0 & 14.00 & 14.3 & 14.0 & 14.0 & 14.3 & 13.96 \\
\hline $\operatorname{Pr}>\mathrm{F}$ & 0.81 & 0.73 & 0.79 & 0.28 & 0.00 & 0.02 & 0.47 & 0.01 & 0.63 \\
\hline
\end{tabular}

DM: Dry matter; CP: crude protein; NDF: neutral detergent fiber; ADF: acid detergent fiber; Hc: hemicellulose; Celul: cellulose; Lig: lignin; ME: metabolizable energy. CV: coefficient of variation.

Means in column with different letters differ according to Duncan's test $(\mathrm{P}<0.05)$ 
Table 5. Thoracic diameter $(\mathrm{cm})$ of creole kids fed a diet with different proportions of Atriplex nummularia.

\begin{tabular}{|c|c|c|c|c|c|c|c|c|c|}
\hline \multirow{3}{*}{$\begin{array}{l}\text { A. nummularia } \\
(\%)\end{array}$} & \multicolumn{9}{|c|}{ Dates } \\
\hline & \multicolumn{3}{|c|}{ March } & \multicolumn{3}{|c|}{ April } & \multicolumn{3}{|c|}{ May } \\
\hline & 12 & 19 & 26 & 2 & 9 & 16 & 23 & 30 & 7 \\
\hline 0 & 58.17 & 54.67 & 54.75 & 56.92 & 59.08 & 60.33 & 63.18 & 64.18 & 66.09 \\
\hline 10 & 58.91 & 56.46 & 55.46 & 57.36 & 59.55 & 60.44 & 61.27 & 61.82 & 62.55 \\
\hline 20 & 59.50 & 59.25 & 55.50 & 57.50 & 58.75 & 62.27 & 62.55 & 63.00 & 64.36 \\
\hline 30 & 60.33 & 57.33 & 55.67 & 57.33 & 58.75 & 59.33 & 60.33 & 60.75 & 61.58 \\
\hline 40 & 59.83 & 59.08 & 56.92 & 58.67 & 60.08 & 60.58 & 61.08 & 61.33 & 60.67 \\
\hline $\operatorname{Pr}>F$ & 0.99 & 0.82 & 0.99 & 1.00 & 1.00 & 0.98 & 0.97 & 0.95 & 0.79 \\
\hline $\mathrm{CV}, \%$ & 19.34 & 18.45 & 20.01 & 20.09 & 20.18 & 18.72 & 18.03 & 17.69 & 17.85 \\
\hline
\end{tabular}

CV: Coefficient of variation.

Table 6. Height at withers $(\mathrm{cm})$ of creole kids fed a diet with different Atriplex nummularia proportions.

\begin{tabular}{|c|c|c|c|c|c|c|c|c|c|}
\hline \multirow{3}{*}{$\begin{array}{l}\text { A. nummularia } \\
(\%)\end{array}$} & \multicolumn{9}{|c|}{ Dates } \\
\hline & \multicolumn{3}{|c|}{ March } & \multicolumn{3}{|c|}{ April } & \multicolumn{3}{|c|}{ May } \\
\hline & 12 & 19 & 26 & 2 & 9 & 16 & 23 & 30 & 7 \\
\hline 0 & 48.2 & 50.3 & 51.0 & 51.2 & 51.3 & 51.8 & 52.0 & 51.3 & 51.8 \\
\hline 10 & 47.8 & 49.4 & 50.3 & 50.9 & 51.5 & 51.9 & 51.8 & 52.6 & 52.5 \\
\hline 20 & 48.8 & 49.7 & 50.3 & 50.8 & 51.3 & 52.1 & 52.5 & 52.8 & 51.9 \\
\hline 30 & 48.9 & 49.2 & 49.8 & 50.7 & 51.4 & 51.9 & 52.5 & 53.0 & 52.6 \\
\hline 40 & 46.9 & 48.7 & 51.2 & 51.7 & 51.9 & 53.3 & 54.1 & 55.3 & 53.9 \\
\hline $\operatorname{Pr}>\mathrm{F}$ & 0.9 & 0.83 & 0.79 & 0.92 & 0.98 & 0.76 & 0.46 & 0.12 & 0.55 \\
\hline $\mathrm{CV}, \%$ & 8.03 & 6.82 & 5.88 & 5.83 & 5.78 & 5.92 & 6.11 & 6.65 & 6.27 \\
\hline
\end{tabular}

$\mathrm{CV}$ : Coefficient of variation.

Table 7. Weekly weight and total gain of kids fed with different proportions of Atriplex nummularia hay.

\begin{tabular}{|c|c|c|c|c|c|c|c|c|c|c|}
\hline \multirow{3}{*}{$\begin{array}{l}\text { A. nummularia } \\
(\%)\end{array}$} & \multicolumn{10}{|c|}{ Dates } \\
\hline & \multicolumn{3}{|c|}{ March } & \multicolumn{3}{|c|}{ April } & \multicolumn{3}{|c|}{ May } & \multirow{2}{*}{$\begin{array}{l}\text { Total } \\
\text { gain }\end{array}$} \\
\hline & 12 & 19 & 26 & 2 & 9 & 16 & 23 & 30 & 7 & \\
\hline$\%$ & & & & & $-\mathrm{kg}-$ & & & & & \\
\hline 0 & $-0.89 b$ & $0.05 \mathrm{a}$ & 0.50 & 0.55 & 0.25 & 0.25 & 0.27 & $0.43 \mathrm{a}$ & $-1.24 b$ & $1.39 \mathrm{a}$ \\
\hline 10 & $-0.59 \mathrm{ab}$ & $-0.29 a$ & 0.51 & 0.53 & 0.22 & 0.20 & 0.15 & $0.14 b$ & $-1.30 \mathrm{~b}$ & $0.88 \mathrm{ab}$ \\
\hline 20 & $-0.04 a$ & $-0.90 \mathrm{~b}$ & 0.50 & 0.29 & 0.30 & 0.06 & 0.18 & $0.27 \mathrm{ab}$ & $-0.19 a b$ & $0.57 \mathrm{~b}$ \\
\hline 30 & $-0.72 a b$ & $-0.40 \mathrm{ab}$ & 0.37 & 0.39 & 0.18 & 0.20 & 0.13 & $0.20 \mathrm{~b}$ & $0.08 \mathrm{ab}$ & $0.32 b$ \\
\hline 40 & $-0.04 \mathrm{ab}$ & $-0.50 \mathrm{ab}$ & 0.45 & 0.29 & 0.15 & 0.15 & 0.05 & $-0.21 \mathrm{c}$ & $0.77 \mathrm{a}$ & $0.18 \mathrm{~b}$ \\
\hline $\operatorname{Pr}>\mathrm{F}$ & 0.05 & 0.02 & 0.88 & 0.25 & 0.51 & 0.38 & 0.27 & 0.01 & 0.12 & 0.015 \\
\hline $\mathrm{CV}, \%$ & -160.4 & -161.9 & 83.4 & 91.5 & 93.6 & 130.8 & 145.4 & 133.4 & -633.4 & 137.8 \\
\hline
\end{tabular}

CV: Coefficient of variation.

Means in a column with different letters differ according to Duncan's test $(\mathrm{P}<0.05)$.

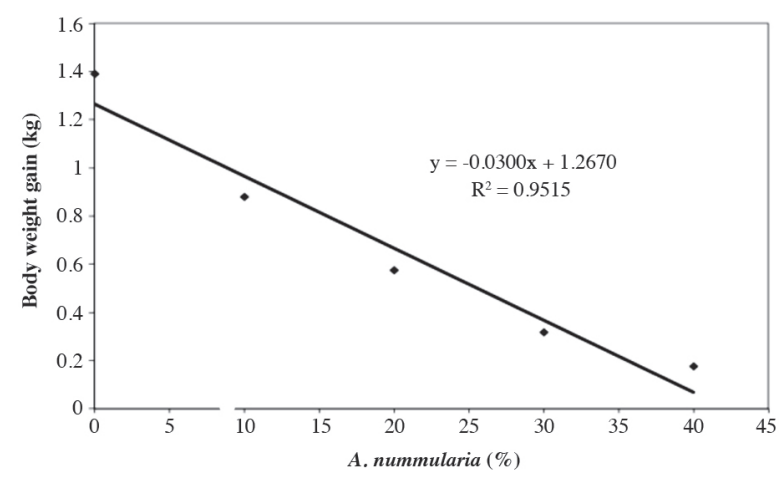

Figure 1. Regression of kid body total gain and Atriplex nummularia included in alfalfa basal diet.

period of about $21 \mathrm{~d}$. Subsequently, weight stabilized until the last assessment, when the weekly weight decreased again for the first 3 treatments with no explanation for these losses. As previously stated, all the animals consumed the same nutrient contents, except for the high ash consumption due to an increase of Atriplex hay in the diets and a lack of metabolizable energy, which can explain the variations. It is also possible that there is a lower digestibility of the diet due to added $A$. nummularia and the effect of salt content in the ruminal environment by rumen osmolality changes. Masters et al. (2005b) reported depressed feed intake and digestibility of halophyte shrub intake. This will therefore decrease growth rates or weight loss.

Analysis of the cumulative weight gain in the whole trial period results in significant differences (Table 7), which can be attributed to small differences that accumulate over time due to energy limitation, DM consumption, high ash, and $\mathrm{Cl}$ and $\mathrm{Na}$ intake. The latter can cause mineral imbalance (Masters et al., 2007) when consumption is over a long period of time. Ben Salem et al. (2010) state that a large proportion of $A$. nummularia non-protein $\mathrm{N}$ and ruminal protein synthesis require energy to synthesize microbial protein or else ammonia is absorbed and excreted in the urine. However, the differences found in this research are not very extensive and adding an energy source can improve the productive parameters. Norman et al. (2008) improved body and weight conditions and wool production by supplementing with grain and 
reduced weight and body condition losses of sheep fed with A. nummularia. Ben Salem et al. (2002a; 2002b) also succeeded in increasing the productive response by increasing diet energy content.

Although most of the diet chemical components showed no significant differences, the total weight gain of kids fed Atriplex did have statistical differences when $20 \%$ Atriplex was included in the diet. The evaluation trial period was 2 mo and the effect was inconsistent and cumulative; Atriplex feeding over a short period of time probably has a low effect for this reason.

The regression analysis is statistically significant $(\mathrm{P}$ $<0.05$ ) for a lineal model of kid body total gain and $A$. nummularia inclusion percentage.

\section{Carcass composition}

The ANOVA of carcass and components showed no significant effect on these parameters, except for kidney weight, commercial yield, and autopod performance ( $P>0.05$ Tables 8 and 9). No statistical differences are expected given the results obtained from the weight, height, and thoracic diameter variations.

Table 8. Carcass component of kids fed with different proportions of Atriplex nummularia hay.

\begin{tabular}{|c|c|c|c|c|c|c|c|}
\hline \multirow[b]{2}{*}{ Components } & \multicolumn{5}{|c|}{ A. nummularia (\%) } & \multirow[b]{2}{*}{$\operatorname{Pr}>F$} & \multirow{2}{*}{$\begin{array}{l}\mathrm{CV} \\
(\%)\end{array}$} \\
\hline & 0 & 10 & 20 & 30 & 40 & & \\
\hline $\begin{array}{l}\text { Slaughter weight, } \mathrm{kg} \\
\text { Carcass weight }\end{array}$ & 15.71 & 14.53 & 15.58 & 16.29 & 16.21 & 0.933 & 20.02 \\
\hline Warm, with/head & 7.23 & 6.63 & 7.13 & 5.86 & 6.18 & 0.55 & 20.21 \\
\hline Warm, without/head & 6.21 & 5.67 & 6.23 & 4.98 & 5.30 & 0.44 & 19.53 \\
\hline Cold, without/head & 6.26 & 5.72 & 6.28 & 5.04 & 5.35 & 0.45 & 19.35 \\
\hline Head weight, kg & 1.01 & 0.87 & 0.91 & 0.79 & 0.88 & 0.56 & 20.22 \\
\hline Blood weight, $\mathrm{kg}$ & 0.91 & 9.78 & 0.82 & 0.69 & 0.75 & 0.57 & 23.05 \\
\hline Skin weight, kg & 1.20 & 1.02 & 0.89 & 0.90 & 0.99 & 0.29 & 20.93 \\
\hline \multicolumn{8}{|l|}{ Autopod weight, $\mathrm{kg}$} \\
\hline Right hand & 0.10 & 0.097 & 0.102 & 0.112 & 0.080 & 0.39 & 22.88 \\
\hline Left hand & 0.10 & 0.097 & 0.112 & 0.102 & 0.077 & 0.33 & 23.41 \\
\hline \multicolumn{8}{|l|}{ Digestive system, $\mathrm{kg}$} \\
\hline Full weight, kg & 5.33 & 4.68 & 5.48 & 5.54 & 5.98 & 0.74 & 24.78 \\
\hline Empty weight, kg & 3.07 & 2.72 & 3.00 & 2.57 & 2.76 & 0.79 & 22.69 \\
\hline Ruminal content weight, $\mathrm{kg}$ & g 2.26 & 1.96 & 2.48 & 2.98 & 3.21 & 0.16 & 20.01 \\
\hline Heart weight, $\mathrm{kg}$ & 0.07 & 0.07 & 0.09 & 0.08 & 0.07 & 0.74 & 34.37 \\
\hline Lung weight, $\mathrm{kg}$ & 0.18 & 0.14 & 0.19 & 0.17 & 0.13 & 0.15 & 21.65 \\
\hline Right kidney weight, $\mathrm{kg}$ & $0.06 \mathrm{a}$ & $0.05 \mathrm{a}$ & $0.05 \mathrm{a}$ & $0.05 \mathrm{ab}$ & $0.03 b$ & 0.03 & 20.91 \\
\hline Left kidney weight, $\mathrm{kg}$ & $0.06 \mathrm{a}$ & $0.05 \mathrm{a}$ & $0.05 \mathrm{a}$ & $0.05 \mathrm{ab}$ & $0.03 b$ & 0.03 & 20.91 \\
\hline Pancreas weight, $\mathrm{kg}$ & 0.06 & 0.04 & 0.05 & 0.04 & 0.04 & 0.32 & 21.00 \\
\hline Liver weight, $\mathrm{kg}$ & 0.26 & 0.22 & 0.30 & 0.22 & 0.22 & 0.19 & 22.72 \\
\hline Eye loin, $\mathrm{cm}^{2}$ & 5.40 & 5.09 & 5.03 & 4.14 & 4.24 & 0.33 & 20.91 \\
\hline
\end{tabular}

CV: Coefficient of variation.

Means with different letters in a row are significantly different $(\mathrm{P}<0.05)$

Table 9. Carcass component yields of kids fed with different proportions of Atriplex nummularia.

\begin{tabular}{|c|c|c|c|c|c|c|c|}
\hline \multirow{2}{*}{ Yiel (\%) } & & \multicolumn{4}{|c|}{ A. nummularia (\%) } & \multirow[b]{2}{*}{$\operatorname{Pr}>\mathrm{F}$} & \multirow{2}{*}{$\begin{array}{l}\text { CV } \\
(\%\end{array}$} \\
\hline & & 0 & 10 & 20 & 30 & & \\
\hline Commercial & $39.95 \mathrm{a}$ & $39.58 \mathrm{a}$ & $40.48 \mathrm{a}$ & $31.22 \mathrm{~b}$ & 37.71ab & 0.024 & 11.66 \\
\hline Truth & 46.62 & 45.71 & 47.84 & 38.38 & 42.67 & 0.278 & 14.33 \\
\hline Red remains & 0.67 & 0.57 & 0.72 & 0.59 & 0.53 & 0.31 & 21.75 \\
\hline Head & 7.518 & 7.013 & 6.95 & 6.00 & 7.01 & 0.45 & 16.05 \\
\hline Digestive tract & 22.71 & 21.46 & 23.24 & 19.47 & 22.02 & 0.119 & 15.80 \\
\hline Skin & 8.90 & 8.12 & 6.77 & 6.85 & 7.93 & 0.12 & 15.80 \\
\hline Autopod & $3.11 \mathrm{a}$ & $3.02 \mathrm{a}$ & $3.22 \mathrm{a}$ & $3.12 \mathrm{a}$ & $2.23 b$ & 0.03 & 14.09 \\
\hline
\end{tabular}

CV: Coefficient of variation.

Means with different letters in a row are significantly different $(\mathrm{P}<0.05)$
The effect of kidney weight could be linked to the fact that $\mathrm{Cl}$ and $\mathrm{Na}$ consumption for the $30 \%$ A. nummularia diet was 3.87 and 10.78 times the control intake, respectively. These values are 4.85 and 14.98 times the control intake, respectively, in the case of the $40 \%$ treatment and excess salt is eliminated by the kidney.

The commercial yield could have been influenced by the lower empty weight of the $30 \%$ and $40 \% \mathrm{~A}$. nummularia treatments, although this component did not show any statistical differences. In the case of autopods, the inclusion of $40 \%$ Atriplex hay was significantly less than the other treatments and the cumulative effect could have caused a difference in the performance of this component.

There are no recent publications about the characterization of native goat kid carcasses in the country. Meneses et al. (2004) present values of creole animals that are higher than those found in this paper, but the animals were slaughtered at heavier weights.

\section{CONCLUSIONS}

A $10 \%$ proportion of $A$. nummularia hay added to an alfalfa hay basal diet has no effect on goat kid total weight gain. Higher proportions limit this parameter. Thoracic diameter and height at withers were not affected by including $A$. nummularia to an alfalfa hay basal diet. The energy contribution of $A$. nummularia apparently causes limitations. Therefore, energy supplementation is important to obtain positive results. Except for higher kidney weight, none of the A. nummularia hay proportions used in the diets had any effect on goat kid carcasses. Moreover, it is necessary to indicate that the consumption of $\mathrm{Cl}$ and $\mathrm{Na}$ is very high.

Evaluación del uso de heno de Atriplex nummularia en el consumo de alimento, crecimiento y características de canal de cabritos criollos. Existe excedente del pastoreo de Atriplex nummularia Lindl. que puede ser usado en la alimentación animal. Este material fue cosechado para evaluar el efecto en el consumo, crecimiento y en las características de canal de caprinos. El Atriplex fue entregado en reemplazo de heno de alfalfa (Medicago sativa L.) en una proporción de 0, 10, 20, 30 y $40 \%$, a 60 crías criollas, de $13 \mathrm{~kg}$ de peso, asignadas a las cinco dietas, en un diseño completamente al azar, entre marzo y mayo. El consumo individual se evaluó en dos hembras y dos machos por grupo. La altura a la cruz, variación de peso y diámetro de tórax fueron evaluados en todos los animales. Las canales se evaluaron en cuatro hembras por grupo. Muestras de heno, dietas ofrecidas y rechazadas fueron analizadas químicamente. El contenido de proteína cruda (PC), energía metabolizable (EM), Cl y $\mathrm{Na}$ del Atriplex fue de 20,20\%, 1,99 Mcal kg-1 , 4,78 y $6,47 \%$, respectivamente. El consumo de hemicelulosa (Hc), cenizas (Cen), diámetro torácico, altura a la cruz, 
y componentes de la canal, exceptuado los riñones, no fueron diferentes $(\mathrm{P}>0,05)$ entre tratamientos. Por sobre $20 \%$ de $A$. nummularia en la dieta se incrementa el consumo de minerales $(\mathrm{P}>0,05)$. La ganancia total de peso disminuyó $(\mathrm{P}<0,05)$ con la incorporación de $20 \%$ o más de Atriplex. La incorporación de hasta $20 \%$ de Atriplex no provoca efectos negativos, mayores porcentajes disminuyen las ganancias de pesos atribuibles al alto contenido de $\mathrm{Na}$ y $\mathrm{Cl}$.

Palabras clave: Atriplex nummularia, caprinos, heno.

\section{LITERATURE CITED}

Aganga, A., J.K. Mthetho, and S. Tshwenyane. 2003. Atriplex nummularia (Old man Saltbush): A potential forage crop for arid regions of Botswana. Pakistan Journal of Nutrition 2:72-75.

AOAC. 1990. Official method of analyses. $134 \mathrm{p} .15^{\text {th }}$ ed. Association of Official Analytical Chemists (AOAC), Arlington, Virginia, USA.

Ben Salem, H., A. Nefzaoui, and L. Ben Salem. 2002a. Supplementation of Acacia cyanophylla Lindl. foliage-based diets with barley or shrubs from arid areas (Opunta ficus-indica f. inermis and Atriplex nummularia Lindl.) on growth and digestibility in lambs. Animal Feed Science and Technology 96:15-30.

Ben Salem, H., A. Nefzaoui, and L. Ben Salem. 2002b. Opuntia ficusindica F. inermis and Atriplex nummularia L.: Two complementary fodder shrubs for sheep and goats. Acta Horticulturae 581:333334.

Ben Salem, H., H.C. Norman, A. Nefzaoui, D.E. Mayberry, K.L. Pearce, and D.K. Revell. 2010. Potential use of oldman salt bush (Atriplex nummularia Lindl.) in sheep and goat feeding. Small Ruminant Research 91:13-28.

Jahn, E., P. Soto, P. Cofré, y R. Sasmay. 2003. Velocidad de secado de alfalfa bajo diferentes condiciones de radiación y ancho de hilerado. Agricultura Técnica 63:30-37.

Lailhacar, S., y C. Torres. 2001. Influencia de los arbustos del género Atriplex con y sin corte de rebaje en el comportamiento del estrato herbáceo del secano árido. I. Efecto del arbusto promedio del género sobre las características cuantitativas del estrato herbáceo total. Avances en Producción Animal 26:79-96.

López, J., J. Capote, y M. Fresno. 1992. Rendimiento de la canal de cabritos de la Agrupación Caprina Canaria (ACC) en los primeros dos meses de vida. Tierra Árida 11:60-67.

Masters, D.G., S.E. Benes, and H.C. Norman. 2007. Biosaline agriculture for forage and livestock production. Agriculture, and Ecosystems and Environment 119:234-248.
Masters, D.G., H.C. Norman, and E.G. Barret-Lennard. 2005a. Agricultural systems for saline soil: the potential role of livestock. Asian-Australasian Journal of Animal Science 18:296-300.

Masters, D.G., A.J. Rintoul, E.A. Dynes, K.L. Pearce, and H.C. Norman. 2005b. Feed intake and production in sheep fed diets high in sodium and potassium. Australian Journal of Agricultural Research 56:427-434.

Meneses, R., A. Rojas, H. Flores, y O. Romero. 2004. Rendimientos y composición de canales de cabritos criollos de híbridos Cashmere. Archivos de Zootecnia 53:107-110.

Meneses, R., y F. Squella. 1996. Los arbustos forrajeros. p. 150-170. In Ruiz I. (ed.) Praderas para Chile. Instituto de Investigaciones Agropecuarias INIA, Santiago, Chile.

Norman, H.C., C. Friend, D.G. Masters, A.J. Rintoul, R.A. Dynes, and I.H. Williams. 2004. Variation within and between two saltbush species in plant composition and subsequent selection by sheep. Australian Journal of Agricultural Research 55:999-1007.

Norman, H.C., D.G. Masters, M.G. Wilmont, and A.J. Rintoul. 2008. Effect of supplementation with grain, hay or straw on the performance of weaner merino sheep grazing old man (Atriplex nummularia) or river (Atriplex amnicola) saltbush. Grass and Forage Science 63:179-192.

NRC. 1981. Nutrient requirements of domestic animals. Nutrient requirements of goats: Angora, dairy and meat goats in temperate and tropical countries. 91 p. National Academy Press, Washington D.C., USA.

SAS Institute. 1998. SAS/STAT User's guide. Version 6.06. 1028 p. SAS Institute, Cary, North Carolina, USA.

Steel, H.G., and J.H. Torrie. 1980. Principles and procedure of statistics: with special references to the biological science. $481 \mathrm{p}$. $2^{\text {nd }}$ ed. MacGraw-Hill Book Co., New York, USA.

Thomas, D.T., A.J. Rintoul, and D.G. Masters. 2007. Sheep select combinations of high and low sodium chloride, energy and crude protein feed that improve their diet. Applied Animal Behaviour Science 105:140-153

Tilley, M., and R.A. Terry. 1963. A two stage techniques for in vitro digestion of forage crops. Journal of the British Grassland Society 18:104-111.

van Soest, P. 1963. Use of detergents in the analysis of fibrous feeds. II. A rapid method for determination of fiber and lignin. Journal of the Association of Official Analytical Chemists 46:829-834.

Wilmot, M., and H. Norman. 2006. Saltbush biomass in saline grazing system-uses it or loses it. In Adams, N. (ed.) Animal production in Australia. Proceeding of the Australian Society of Animal Production $26^{\text {th }}$ Biennial Conference, Perth, Australia. Short Communications $\mathrm{N}^{\circ}$. Available at http//www.asap.asn.au/ asap28/proceedings/short-comms-2006. (Accessed: March 2011). 